\title{
A Comparison of Contiguous Two-level Anterior Cervical Discectomy and Fusion using a Structural Allograft versus a Polyetheretherketone (PEEK) Cage: The Results of a Three-Year Follow-up
}

ING HOW MOO ( $\square$ zell53@hotmail.com )

Singapore General Hospital https://orcid.org/0000-0002-3862-835X

\section{Carmen Jia Wen Kam}

Changi General Hospital

\section{Maksim Wen Sheng Lai}

Singapore General Hospital

William Yeo

Singapore General Hospital

Reuben Chee Cheong Soh

Singapore General Hospital

\section{Research article}

Keywords: cervical, ACDF, allograft, polyetheretherketone, PEEK

Posted Date: July 16th, 2019

DOl: https://doi.org/10.21203/rs.2.11416/v1

License: (c) (i) This work is licensed under a Creative Commons Attribution 4.0 International License. Read Full License

Version of Record: A version of this preprint was published at BMC Musculoskeletal Disorders on May 28th, 2020. See the published version at https://doi.org/10.1186/s12891-020-03325-y. 


\section{Abstract}

Background: The effectiveness of graft type in two-level anterior cervical discectomy and fusion (ACDF) with plate fixation remains controversial. The primary aim of this retrospective study is to compare the clinical and radiological outcomes of two-level anterior cervical decompression and fusion (ACDF) with plate fixation using either a structural allograft or a polyetheretherketone (PEEK) cage. Methods: From 2010 to 2015, 88 consecutive patients underwent a two-level ACDF of which 53 used an allograft and 35 patients with a PEEK cage. All clinical outcomes were prospectively collected preoperatively, at six months and at two years after surgery. Clinical efficacy was evaluated using visual analogue scale for neck pain and limb pain, the Neck Pain and Disability Score, Neck Disability Index, Neurogenic Symptom Score, and the Japan Orthopedic Association score. Radiological outcomes were assessed preoperatively, immediately after surgery, and at the final follow-up. Results: A preoperative comparison revealed no difference between the two patient groups in terms of age, gender, body mass index, smoking status, preoperative symptoms, operated levels, and follow-up (mean= 42.8 months). No difference in improvements in the clinical outcome between the two groups was observed. Both groups showed significant improvement in mean disc height, segmental height, and segmental lordosis postoperatively. The fusion rates for PEEK cage was $100 \%$ at both levels while the fusion rates for allograft group was $98.1 \%$ at cephalad level and $94.2 \%$ at caudad level ( $p>0.05)$. Subsidence at the cephalad level occurred in $22.9 \%(8 / 35)$ segments in the PEEK group and 7.7\% (4/52) segments in the allograft group $(p=0.057)$. At the caudal level, a higher cage subsidence was noted in the PEEK group compared to the allograft group [37.1\% (13/35) versus $15.4 \%(8 / 52)](p=0.02)$. Overall, subsidence was noted in $30 \%(21 / 70)$ of the PEEK group and in $11 \%(12 / 104)$ of the allograft group $(p<0.05)$. Conclusion: The use of PEEK cages resulted in a higher rate of subsidence in two-level ACDF as compared to allograft. Two-level ACDF using either allografts or PEEK cages resulted in similar clinical outcomes, radiological improvements in alignment and fusion rates.

\section{Background}

Anterior cervical decompression and fusion (ACDF) was first described by Smith and Robinson in 1955 and has since become a highly effective procedure to treat degenerative cervical disc disease (1). However, the success rate declines in multilevel ACDF because contact stress and micromotion increase at the graft-body interface which may affect fusion as well as maintenance of height of the neural foramen (2).

The ideal interbody graft material for use in this procedure remains to be determined. The use of an autologous iliac crest (AIC) bone graft is considered by many to be the gold standard to achieve a high interbody fusion rate. However, AIC harvesting has a $13 \%$ donor site complication rate $(3,4)$. This is the impetus to seek the use of several different biomaterials to allow maintenance of the disc height and subsequent fusion across the interbody space.

Allografts and polyetheretherketone (PEEK) cages are the two most commonly used material in ACDF and make up $92 \%$ of interbody cage use (5). Since their commercial release in 1998, PEEK cages have been widely used despite the lack of evidence on the outcome of their use compared with allograft interbody cages (6).

To the authors' knowledge, there is no study that directly compares the outcomes of using a PEEK cage versus an allograft in two-level contiguous ACDF. The primary aim of this study is to evaluate the long-term clinical efficacy and radiological outcomes of two-level ACDF with plate fixation using either a structural allograft or a PEEK cage.

\section{Methods}

The approval of the Centralized Institutional Review Board of Singhealth was obtained (CRIB: 2017/2628). All patients who underwent two-level contiguous ACDF surgery using either PEEK cages (Cornerstone ${ }^{\circledR}$, Medtronic Sofamor-Danek, Memphis, TN, USA; $\operatorname{Cervios}^{\circledR}$, Synthes, Zuchwil, Switzerland; Solis ${ }^{\circledR}$ Stryker Spine, Allendale, NJ) or allografts (Triad ${ }^{\circledR}$ Allograft system, Nuvasive, Inc.) from 2010 to 2015 were selected. 
For this study, only patients who underwent surgery for degenerative cervical disc disease and spondylosis and who had a minimum two-year follow-up were included. Indications for surgery were symptomatic cervical radiculopathy, myelopathy or myelo-radiculopathy with demonstrable correlated compression based on preoperative magnetic resonance imaging (MRI). Patients with neurological disorders, psychiatric illness, tumours, fractures, previous cervical spine surgery, or infections were excluded.

All surgeries were performed in a single centre by orthopaedic spine surgeons using standard operative techniques as described. A Smith-Robinson approach to the anterior cervical spine was performed. Once the operative level was identified radiologically, Caspar pins and retractors were used to secure exposure. Microsurgical decompression was then performed extending laterally to the uncinate processes with partial removal of the posterior uncinate process to free the neural elements. The posterior longitudinal ligament was subsequently resected. Endplate preparation involved the use of a high speed burr to remove the overlying cartilage up to the bleeding subchondral bone. An optimal size interbody graft was selected and inserted into the disc space. Either a PEEK cage or an allograft was used as an interbody graft, depending on the surgeon's preference. All PEEK cages were filled with local autografts from anterior osteophytes as well as shavings from the burring of the uncinate process. A cervical plate and screws were used for fixation in all cases of ACDF. An Aspen cervical collar was used for six weeks postoperatively. All patients were managed postoperatively according to our institution's cervical spinal surgery clinical pathway, and all underwent the same physiotherapy protocol.

\section{Outcomes Assessment}

Demographics, perioperative details, and clinical outcomes were independently and prospectively collected at our institution's Orthopaedic Diagnostic Centre, which evaluates all patients undergoing spine surgery preoperatively and postoperatively at six months and two years. Next, a retrospective analysis of the data was performed. The following outcome scales were used: Neck Pain and Disability (NPD) scale, American Academy of Orthopaedic Surgeons Neurogenic Symptom Score (AAOS-NSS), the Neck Disability Index (NDI), visual analogue scale for neck pain (VASNP), visual analogue scale for limb pain (VASLP), and Japanese Orthopedic Association (JOA) score.

Radiographs were taken before surgery, immediately after surgery, and at the last follow-up. Digital radiographs stored in the Picture Archiving and Communication System were used to measure distances and angles up to the accuracy of $0.01 \mathrm{~mm}$ and 0.1 degrees, respectively. Radiological parameters assessed for each level include mean disc height, segmental height, segmental Cobb angle, and the C2-C7 Cobb angle (Figure 1). Subsidence was defined as the loss of segmental height more than $2 \mathrm{~mm}$ at the final follow-up compared to the segmental height measured immediately after surgery. In accordance with current evidence, fusion was defined by 1) the interspinous distance method (lack of movement at operated levels with interspinous process motion $<1 \mathrm{~mm}$ difference in flexion and extension in a satisfactory film, which is defined as the presence of interspinous process motion of at least $4 \mathrm{~mm}$ at the uninvolved adjacent segment), 2) the presence of a bridging bone across the fusion level observed on a computer tomography (CT) scan or a plain radiograph at the last follow-up, and 3) the absence of radiolucency at the graft-vertebral junction (7). There were no patients in our study with postoperative infection or reoperation within an average of 3 years of follow up.

\section{Statistical Analysis}

Statistical analysis was performed by a statistician using SPSS statistical software, version 19.0 (IBM Corp. Armonk, NY). Categorical data was presented as frequency (percentage) and examined using a Chi-squared test. Numeric data was presented as mean \pm standard deviation for parametric distribution and median (interquartile range) for non-parametric distribution. A twosample t-test was used to evaluate the numerical variables. For clinical and radiological outcomes, a two-way repeated measures ANOVA was used to examine the significance of the group*time interaction and the main effects of groups and time. If there was a

Page 3/12 
significant group*time interaction, a subgroup analysis of groups and time was performed, and the simple main effects of group type and time were tested independently. If there was no significant interaction, the main effects of protocol type and time were reported. A two-tailed $p$-value of $<0.05$ was considered statistically significant.

\section{Results}

88 cases of two-level ACDF with either allografts $(n=53)$ or PEEK cages $(n=35)$ matched the strict inclusion criteria. A preoperative comparison showed there was no statistical difference between patients who had PEEK cages versus allografts in terms of age, gender, body mass index, smoking status, preoperative symptoms, operated levels, and preoperative scores of NPD, AAOS-NSS, NDI, VASNP, and VASLP (p>0.05) (Table 1). The allograft group had a higher JOA score at baseline than the PEEK group. Both groups had postoperative followups of similar duration (mean= 42.8 months, ranged from 24-58 months). No instances of complications were reported in either group.

At six months and two years postoperatively, both groups demonstrated significant improvements in NPD, NS, NDI, JOA, VASNP, and VASLP, but there were no significant differences between the two groups (Table 2). Although both groups had similar JOA scores at six months postoperatively $(p=0.137)$, the allograft group had a higher JOA score at two years postoperatively than the PEEK group $(p=0.03)$.

At both operated levels, both groups demonstrated significant improvement in mean disc height and segmental height immediately after surgery. Loss of mean disc height and segmental height were noted in both groups at both levels at the final follow-up. There was no difference in mean disc height and segmental height $(p>0.05)$ between the two groups immediately after surgery and at the last follow-up (Table 3).

At the cephalad level, the PEEK group had greater segmental lordosis than the allograft group before surgery $(p=0.011)$ (Table 1). Immediately after surgery, segmental lordosis remained unchanged in the PEEK group $(\mathrm{p}=0.852)$, while the allograft group demonstrated significant improvement at the cephalad level $(p<0.001)$. At the caudal level, both groups demonstrated significant improvement in segmental lordosis immediately after surgery $(p<0.001)$.There was no difference in the segmental Cobb angle between the two groups at both levels immediately after surgery or at the final follow-up ( $\mathrm{p}>0.05)$. Both groups demonstrated significant loss of segmental Cobb angle at both levels at the final follow-up $(\mathrm{p}<0.004)$.

Both groups had similar cervical Cobb angles at baseline and immediately after surgery $(\mathrm{p}=0.130$ and $\mathrm{p}=0.532$, respectively). At the last follow-up, cervical lordosis was maintained in both groups; there was no difference between the groups ( $p>0.05)$.

Concerning cage subsidence, subsidence at the cephalad level occurred in $22.9 \%(8 / 35)$ segments in the PEEK group and 7.7\% (4/52) segments in the allograft group ( $\mathrm{p}=0.057)$. At the caudal level, a higher cage subsidence was noted in the PEEK group compared to the allograft group [37.1\% (13/35) versus 15.4\% $(8 / 52)](p=0.02)$ (Table 4). Overall, the subsidence rate was 30\% (21/70) and 11\% $(12 / 104)$ in the PEEK and allograft groups, respectively $(\mathrm{p}<0.05)$.

At the last follow-up, 55 cases had fusion assessment using flexion-extension radiographs and the interspinous process method ( $<1 \mathrm{~mm}$ motion difference), 24 cases were assessed using CT scans, and the remaining 9 cases were assessed using plain radiography. There was no significant difference in the fusion assessment methods between the two groups. The fusion rate for PEEK cages was $100 \%$ at both levels. The fusion rate for the allograft group was $98.1 \%$ at the cephalad level and $94.2 \%$ at the caudal level (overall 96.2\%). There was no significant difference in the union rate between the two groups ( $p>0.05$ ) (Table 4). All non-union cases were nonsmokers. Reoperation for non-fusion was not needed. 


\section{Discussion}

In general, the fusion rate decreases as the number of operative levels increases (8-10). This study directly compares the clinical and radiological outcomes of allografts and PEEK cages in 2 similar groups who underwent two-level ACDF with anterior cervical plating. This study demonstrated 100\% and 96.2\% fusion rates for PEEK cages and allografts, respectively.

Concerning the use of lordotic cages in both PEEK and allograft, demonstrable improvements in lordosis was observed in both groups. However, concerning cage subsidence, it was noted that PEEK cages caused more subsidence than allograft cages. Several reasons may help to explain this. Firstly, although PEEK mimics the elastic modulus of bone, it is non-resorbable and may result in point loading. Secondly, there is emerging evidence of the presence of fibrous tissues on the bone-implant interface (11) which can slow down osteointegration leading to a higher micromotion. In vitro studies have also demonstrated that the osteoblastic differentiation of progenitor cells is reduced on the surface of PEEK cages and that inflammatory chemokines are produced, which may theoretically contribute to subsidence (12). The literature reported a widely ranging subsidence rate in ACDF for both allografts and PEEK cages (5-43\% vs. 8-32\%, respectively) [5]. Yson et al compared the subsidence rates between PEEK cage and allografts and found no significant difference between the PEEK cages (29\%) and the allografts (28\%) [19]. This study included mixed levels of ACDF and defined subsidence using a different criterion.

To date, comparative studies of PEEK cages and allografts in ACDF are of low quality and are heterogeneous. Due to the different cervical biomechanics in single-level versus two-level ACDF, we chose to study only patients with contiguous two-level ACDF (13). Vaidya et al. performed a retrospective study of 46 patients who underwent ACDF with anterior plating (14). PEEK cages filled with recombinant human bone morphogenetic protein-2 (rhBMP-2) (n=22, 8 one-level, 9 two-level, 4 three-level) were compared with allograft spacers and demineralised bone matrices ( $n=24,11$ one-level, 10 two-level, 3 three-level). All patients in the PEEK group achieved union, while 23/24 patients in the allograft group achieved union. The study concluded there was no difference in the arthrodesis rate between the two groups. However, this study included a mix of single-level and multilevel ACDF, and the use of RhBMP-2 in the PEEK group introduced confounding bias in the analysis of the fusion rate between the two groups. Hence, we sought to look at the fusion rate in patients without the use of BMP. Katie et al. retrospectively reviewed 127 cases of single-level ACDF with either PEEK cages or allografts (15). Of the patients involved, 29/56 (52\%) with PEEK cages had pseudarthrosis compared to 7/71 (10\%) patients with allografts. The author concluded that the use of PEEK cages is associated with increased non-union and revision surgery compared to the use of structural allografts. However, there are several confounders that affect the validity of this conclusion, including 69\% loss to follow-up, more smokers in the PEEK group and the use of various types of allografts. In addition, $82 \%$ of the PEEK implants were stand-alone devices, while $100 \%$ of the allograft group had anterior cervical plating. Most recently, Pirkle et al. performed a comparative registry study of 6130 patients with ACDF using either allografts or intervertebral cages (16). Non-union was identified by coding and the analysis included only 3 variables (i.e. smoking, diabetes and operated level). The study concluded that cage group had higher non-union rate than the allograft group. However, there were no demographic data, radiographic analysis of fusion and details of the types of cages placed.

In our study, a fusion of $96.2 \%$ in allografts cages compares favourably with the results in the literature. Allograft cages with anterior cervical plating have previously showed fusion rates from $92-100 \%(4,17)$. Different types of allografts may also explain the widely ranging fusion rate. Allografts vary in bone quality depending on donor population and the type of bone harvested. In addition, the final biomechanical properties of a particular allograft are significantly influenced by its method of preparation, which may vary widely between manufacturers (18). Most commonly used allografts are freeze-dried, high-dose irradiated, and cortical allografts. Cortical allografts lack the three-dimensional bone matrix and have a slower graft incorporation rate compared to cancellous allografts. However, cortical allografts are less likely to collapse. Freeze-drying, especially in conjunction with 
irradiation, can cause a significant reduction in strength. All the allografts in our current study were obtained from the same manufacturer and come as saline-packaged cortical-cancellous allografts obtained from human femurs or tibias and were terminally sterilised with low-dose irradiation to maintain mechanical integrity.

Maintaining cervical disc height after surgery is crucial, as disc height collapse may result in kyphosis formation and accelerate adjacent segment degeneration in the long term (19). In our study, patients in both groups showed significant improvement in mean disc height, segmental height, and segmental lordosis postoperatively. However, there was loss of mean disc height, segmental height, and segmental lordosis at the last follow-up for both groups compared to immediately after surgery. An average of $20 \%$ loss in height at each interspace level can be expected, even after tricortical autograft fusion (4).

Our study has certain limitations, such as its retrospective nature, small sample size, and multiple surgeon series. In addition, the relationship between bone density and cage subsidence was not analysed. The potential measurement error must also be taken into account. It is difficult to accurately evaluate bone bridge formation and assess dynamic motion on the lateral radiographs, and CT scans may not be possible in all cases. The strengths of our study include the uniform use of a single type of allograft, the use of objective clinical data with a validated outcomes survey, strict criteria for subsidence and fusion, the longest ever follow-up in the literature, and the lack of previous head-to-head comparisons of the outcomes of PEEK cages and allografts in two-level ACDF.

Furthermore, our study also demonstrated that subsidence does not impact clinical outcomes, which is consistent with the literature.

\section{Conclusion}

While two-level ACDF using either allografts or PEEK cages resulted in similar clinical outcomes and fusion rates, the subsidence rate was higher with the use of PEEK cages.

\section{Abbreviations}

- ACDF: anterior cervical discectomy and fusion

- PEEK: polyetheretherketone

- AIC: autologous iliac crest

- MRI: magnetic resonance imaging

- NPD: Neck Pain and Disability scale

- AAOS-NSS: American Academy of Orthopaedic Surgeons Neurogenic Symptom Score

- NDI: the Neck Disability Index

- VASNP: visual analogue scale for neck pain

- VASLP: visual analogue scale for limb pain

- JOA: Japanese Orthopedic Association

- CT: computer tomography

- rhBMP-2: recombinant human bone morphogenetic protein-2

\section{Declarations}

- Ethics approval and consent to participate

- Centralized Institutional Review Board of SingHealth (CRIB: 2017/2628)

- Waiver to obtain informed consent was obtained

- Consent for publication 
- Not applicable

- Availability of data and material

- The datasets used and/or analysed during the current study are available from the corresponding author on reasonable request

- Competing interests

- The authors declare that they have no competing interests

- Funding

- All authors did not receive any outside funding or grants in support of their research for preparation of this work

- Authors' contributions

- IH designed the study, analysed and interpreted the data and was the major contributor in writing the manuscript. CJW analysed and interpreted the data. MWS and WY contribute to the acquisition and drafting the manuscript. RCC designed the study, interpreted the data and substantively revised the manuscript. All authors read and approved the final manuscript

- Acknowledgements

- Not applicable

\section{References}

(1) Smith GW, Robinson RA. The treatment of certain cervical-spine disorders by anterior removal of the intervertebral disc and interbody fusion. J Bone Joint Surg Am 1958 Jun;40-A(3):607-624.

(2) Kuhns CA, Geck MJ, Wang JC, Delamarter RB. An outcomes analysis of the treatment of cervical pseudarthrosis with posterior fusion. Spine 2005 Nov 01,;30(21):2424-2429.

(3) Shapiro S, Connolly P, Donnaldson J, Abel T. Cadaveric fibula, locking plate, and allogeneic bone matrix for anterior cervical fusions after cervical discectomy for radiculopathy or myelopathy. J Neurosurg 2001 Jul;95(1 Suppl):43-50.

(4) Deutsch H, Haid R, Rodts G, Mummaneni PV. The decision-making process: allograft versus autograft. Neurosurgery 2007 Jan;60(1 Supp1 1):98.

(5) Yson SC, Sembrano JN, Santos ERG. Comparison of allograft and polyetheretherketone (PEEK) cage subsidence rates in anterior cervical discectomy and fusion (ACDF). J Clin Neurosci 2017 Apr;38:118-121.

(6) Kersten, Roel Frederik Mark Raymond, van Gaalen SM, de Gast A, Öner FC. Polyetheretherketone (PEEK) cages in cervical applications: a systematic review. Spine J 2015 Jun 01;;15(6):1446-1460.

(7) Rhee JM, Chapman JR, Norvell DC, Smith J, Sherry NA, Riew KD. Radiological Determination of Postoperative Cervical Fusion: A Systematic Review. Spine 2015 Jul 01;40(13):974-991.

(8) Samartzis D, Shen FH, Matthews DK, Yoon ST, Goldberg EJ, An HS. Comparison of allograft to autograft in multilevel anterior cervical discectomy and fusion with rigid plate fixation. The spine journal : official journal of the North American Spine Society 2003 Nov;3(6):451.

(9) Kaiser MG, Haid RW, Subach BR, Barnes B, Rodts GE. Anterior cervical plating enhances arthrodesis after discectomy and fusion with cortical allograft. Neurosurgery 2002 Feb;50(2):238. 
(10) Wang JC, McDonough PW, Endow KK, Delamarter RB. Increased fusion rates with cervical plating for two-level anterior cervical discectomy and fusion. Spine 2000 Jan;25(1):41-45.

(11) Takayoshi Shimizu, Shunsuke Fujibayashi, Seiji Yamaguchi, Bungo Otsuki, Yaichiro Okuzu, Tomiharu Matsushita, et al. In vivo experimental study of anterior cervical fusion using bioactive polyetheretherketone in a canine model. PLoS One 2017 Sep 1, ;2(9):e0184495.

(12) Olivares-Navarrete R, Hyzy SL, Slosar PJ, Schneider JM, Schwartz Z, Boyan BD. Implant materials generate different periimplant inflammatory factors: poly-ether-ether-ketone promotes fibrosis and microtextured titanium promotes osteogenic factors. Spine 2015 Mar 15;40(6):399-404.

(13) Dang ABC, Hu SS, Tay BK-. Biomechanics of the anterior longitudinal ligament during $8 \mathrm{~g}$ whiplash simulation following single- and contiguous two-level fusion: a finite element study. Spine 2008 Mar 15;33(6):607-611.

(14) Vaidya R, Carp J, Sethi A, Bartol S, Craig J, Les CM. Complications of anterior cervical discectomy and fusion using recombinant human bone morphogenetic protein-2. Eur Spine J 2007 Aug;16(8):1257-1265.

(15) Krause KL, Obayashi JT, Bridges KJ, Raslan AM, Than KD. Fivefold higher rate of pseudarthrosis with polyetheretherketone interbody device than with structural allograft used for 1-level anterior cervical discectomy and fusion. J Neurosurg Spine 201810 $01,11-6$.

(16) Pirkle S, Kaskovich S, Cook DJ, Ho A, Shi LL, Lee MJ. Cages in ACDF are Associated With a Higher Nonunion Rate Than Allograft: A Stratified Comparative Analysis of 6130 Patients. Spine 2019 Mar 15,;4(6):384-388.

(17) Chau A, Mobbs R. Bone graft substitutes in anterior cervical discectomy and fusion. Eur Spine J 2009 Apr;18(4):449-464.

(18) Zdeblick TA, Ducker TB. The use of freeze-dried allograft bone for anterior cervical fusions. Spine 1991 Jul;16(7):726-729.

(19) Chen Y, Lü G, Wang B, Li L, Kuang L. A comparison of anterior cervical discectomy and fusion (ACDF) using self-locking standalone polyetheretherketone (PEEK) cage with ACDF using cage and plate in the treatment of three-level cervical degenerative spondylopathy: a retrospective study with 2-year follow-up. Eur Spine J 2016 07;25(7):2255-2262.

\section{Tables}

Table 1. Preoperative comparison between Allograft and PEEK groups 


\begin{tabular}{|c|c|c|c|}
\hline Demographics & $\begin{array}{l}\text { Allograft } \\
(\mathrm{n}=53)\end{array}$ & $\begin{array}{c}\text { PEEK } \\
(n=35)\end{array}$ & p-value \\
\hline Male & $27(50.9)$ & $19(54.3)$ & 0.759 \\
\hline Age (years) & 52.4 & 56.0 & \\
\hline Median (IQR) & $(45.2-62.1)$ & $(48.2-63.2)$ & 0.188 \\
\hline BMI & 25.0 & 25.0 & \\
\hline Median (IQR) & $(22.7-27.1)$ & $(23.1-28.2)$ & 0.617 \\
\hline Current smoker & $6(11.5)$ & $4(11.8)$ & 1.000 \\
\hline Symptom & & & 0.335 \\
\hline Radiculopathy & $20(37.7)$ & 8 (22.9) & \\
\hline Myelopathy & $20(37.7)$ & $17(48.6)$ & \\
\hline Radiculomyelopathy & $13(24.5)$ & $10(28.6)$ & \\
\hline Level & & & 0.141 \\
\hline C3-4/C4-5 & $3(5.7)$ & 5 (14.3) & \\
\hline C4-5/C5-6 & $14(26.4)$ & $12(34.3)$ & \\
\hline C5-6/C6-7 & $36(67.9)$ & $16(45.7)$ & \\
\hline C3-4/C5-6* & $0(0.0)$ & $1(2.9)$ & \\
\hline C4-5/C6-7* & $0(0.0)$ & $1(2.9)$ & \\
\hline \multicolumn{4}{|l|}{ Clinical baseline } \\
\hline NPD & $31.3 \pm 20.0$ & $39.9 \pm 26.8$ & 0.111 \\
\hline AAOS-NSS & $47.7 \pm 25.9$ & $49.6 \pm 29.8$ & 0.746 \\
\hline NDI & $30.3 \pm 20.6$ & $38.9 \pm 25.1$ & 0.083 \\
\hline VASNP & $4.8 \pm 3.5$ & $4.6 \pm 3.4$ & 0.751 \\
\hline VASLP & $4.1 \pm 3.9$ & $2.7 \pm 3.2$ & 0.067 \\
\hline JOA & $13.7 \pm 1.9$ & $11.3 \pm 4.3$ & 0.008 \\
\hline \multicolumn{4}{|l|}{ Radiology baseline } \\
\hline $\begin{array}{l}\text { Cervical cobb angle } \\
\text { Cephalic level }\end{array}$ & $7.24 \pm 11.97$ & $10.96 \pm 9.80$ & 0.130 \\
\hline Mean Disc Height & $3.47 \pm 1.07$ & $3.97 \pm 1.25$ & 0.048 \\
\hline Segmental height & $31.32 \pm 3.66$ & $31.57 \pm 4.11$ & 0.769 \\
\hline Segmental Cobb angle & $-1.19 \pm 5.83$ & $2.30 \pm 6.66$ & 0.011 \\
\hline \multicolumn{4}{|l|}{ Caudad level } \\
\hline Mean Disc Height & $3.58 \pm 1.09$ & $3.76 \pm 1.74$ & 0.575 \\
\hline Segmental height & $32.27 \pm 3.51$ & $31.10 \pm 3.41$ & 0.125 \\
\hline Segmental Cobb angle & $3.41 \pm 4.77$ & $2.25 \pm 6.06$ & 0.322 \\
\hline
\end{tabular}

*Small frequency - excluded in the calculation of p-value.

NPD. Neck pain and disability; AAOS-NSS, AAOS neurogenic symptom score; NDI, Neck Disability Index; VASNP, visual analog score neck pain; VASLP, visual analog score limp pain; JOA, Japanese Orthopedic Association Score;

Table 2. Clinical outcomes between the allograft and PEEK group 


\begin{tabular}{|c|c|c|c|c|c|c|c|c|c|c|c|c|}
\hline \multirow{3}{*}{$\begin{array}{l}\text { Clinical } \\
\text { outcome }\end{array}$} & \multirow{2}{*}{\multicolumn{3}{|c|}{ Allograft $(n=53)$}} & & & & \multicolumn{3}{|c|}{ Baseline versus 6-month } & \multicolumn{3}{|c|}{ Baseline versus 2-year } \\
\hline & & & & \multicolumn{3}{|c|}{ PEEK $(\mathrm{n}=35)$} & Interaction & Group & Time & Interaction & Group & Time \\
\hline & Preoperative & $\begin{array}{c}6- \\
\text { month }\end{array}$ & \begin{tabular}{|c|}
$2-$ \\
year
\end{tabular} & Preoperative & $\begin{array}{c}6- \\
\text { month }\end{array}$ & $\begin{array}{c}2- \\
\text { year }\end{array}$ & $\mathrm{p}$-value & $\begin{array}{c}\mathrm{p}- \\
\text { value }\end{array}$ & $\begin{array}{c}\mathrm{p}- \\
\text { value }\end{array}$ & $\mathrm{p}$-value & $\begin{array}{c}\mathrm{p}- \\
\text { value }\end{array}$ & $\begin{array}{c}\mathrm{p}- \\
\text { value }\end{array}$ \\
\hline NPD & $31.2 \pm 20.3$ & $\begin{array}{c}14.0 \\
\pm \\
16.9\end{array}$ & $\begin{array}{c}8.8 \\
\pm \\
12.7\end{array}$ & $39.7 \pm 27.2$ & $\begin{array}{c}20.6 \\
\pm \\
17.4\end{array}$ & $\begin{array}{c}13.4 \\
\pm \\
13.8\end{array}$ & 0.667 & 0.063 & $\begin{array}{c}<< \\
0.001\end{array}$ & 0.365 & 0.052 & $\begin{array}{c}< \\
0.001\end{array}$ \\
\hline NS & $47.3 \pm 26.1$ & $\begin{array}{c}15.7 \\
\pm \\
22.3\end{array}$ & $\begin{array}{c}14.6 \\
\pm \\
21.9\end{array}$ & $50.4 \pm 29.9$ & $\begin{array}{c}18.2 \\
\pm \\
18.8\end{array}$ & $\begin{array}{c}12.8 \\
\pm \\
14.0\end{array}$ & 0.928 & 0.543 & $\begin{array}{c}<< \\
0.001\end{array}$ & 0.649 & 0.929 & $\begin{array}{c}< \\
0.001\end{array}$ \\
\hline NDI & $30.4 \pm 20.9$ & $\begin{array}{c}15.1 \\
\pm \\
16.1\end{array}$ & $\begin{array}{c}10.4 \\
\pm \\
15.1\end{array}$ & $38.5 \pm 25.4$ & $\begin{array}{c}18.5 \\
\pm \\
17.3\end{array}$ & $\begin{array}{c}11.4 \\
\pm \\
11.9\end{array}$ & 0.261 & 0.145 & $\begin{array}{c}<< \\
0.001\end{array}$ & 0.126 & 0.174 & $\begin{array}{c}<< \\
0.001\end{array}$ \\
\hline VASNP & $4.8 \pm 3.6$ & $\begin{array}{c}1.3 \pm \\
2.5\end{array}$ & \begin{tabular}{|c|}
1.0 \\
\pm \\
2.3
\end{tabular} & $4.4 \pm 3.4$ & $\begin{array}{c}1.9 \pm \\
3.0\end{array}$ & $\begin{array}{c}0.9 \\
\pm \\
2.3\end{array}$ & 0.260 & 0.778 & $\begin{array}{c}<< \\
0.001\end{array}$ & 0.939 & 0.832 & $\begin{array}{c}<< \\
0.001\end{array}$ \\
\hline VASLP & $4.1 \pm 3.9$ & $\begin{array}{c}0.8 \pm \\
2.0\end{array}$ & $\begin{array}{c}0.9 \\
\pm \\
2.2\end{array}$ & $2.7 \pm 3.2$ & $\begin{array}{c}0.5 \pm \\
1.7\end{array}$ & $\begin{array}{c}0.2 \\
\pm \\
1.2\end{array}$ & 0.129 & 0.107 & $\begin{array}{c}<< \\
0.001\end{array}$ & 0.451 & 0.087 & $\begin{array}{c}<< \\
0.001\end{array}$ \\
\hline JOA & $13.7 \pm 2.0$ & $\begin{array}{r}15.3 \\
\pm 2.1\end{array}$ & $\begin{array}{c}15.5 \\
\pm \\
2.1\end{array}$ & $11.3 \pm 4.3$ & $\begin{array}{c}14.3 \\
\pm 3.5\end{array}$ & $\begin{array}{c}14.3 \\
\pm \\
3.2\end{array}$ & 0.011 & 0.162 & $<0.001$ & 0.156 & 0.030 & $\begin{array}{c}< \\
0.001\end{array}$ \\
\hline
\end{tabular}

Mean \pm SD. Two-way Repeated Measures ANOVA. Interaction and main effects of groups and time of measurement were assessed. Significance level was set at $\mathrm{p}<0.05$.

ROM, range of motion; NPD, Neck pain and disability; AAOS-NSS, AAOS neurogenic symptom score; NDI, Neck Disability Index; VASNP, visual analog score neck pain; VASLP, visual analog score limp pain; JOA, Japanese Orthopedic Association Score;

Table 3 Radiological outcomes between the allograft and PEEK groups

\begin{tabular}{|c|c|c|c|c|c|c|c|c|c|c|c|c|}
\hline \multirow{3}{*}{$\begin{array}{l}\begin{array}{l}\text { Cephalad } \\
\text { level }\end{array} \\
\text { Radiological } \\
\text { Outcome } \\
\end{array}$} & & & & & & & \multicolumn{3}{|c|}{ Pre-op versus first post-op } & \multicolumn{3}{|c|}{ First post-op versus final post-op } \\
\hline & \multicolumn{3}{|c|}{ Allograft $(n=53)$} & \multicolumn{3}{|c|}{ PEEK $(n=35)$} & Interaction & Group & Time & Interaction & Group & Time \\
\hline & Preop & $\begin{array}{c}1^{\text {st }} \\
\text { post- } \\
\text { op }\end{array}$ & $\begin{array}{c}\text { Final } \\
\text { postop }\end{array}$ & Preop & $\begin{array}{c}1^{\text {st }} \\
\text { post- } \\
\text { op }\end{array}$ & $\begin{array}{c}\text { Final } \\
\text { postop }\end{array}$ & $\mathrm{p}$-value & $\begin{array}{c}\mathrm{p}- \\
\text { value }\end{array}$ & p-value & $\mathrm{p}$-value & $\begin{array}{c}\mathrm{p}- \\
\text { value }\end{array}$ & p-value \\
\hline $\begin{array}{l}\text { Mean Disc } \\
\text { Height }\end{array}$ & $\begin{array}{c}3.47 \pm \\
1.07\end{array}$ & $\begin{array}{c}6.51 \\
\pm \\
0.89\end{array}$ & $\begin{array}{c}5.46 \pm \\
0.89\end{array}$ & $\begin{array}{c}3.97 \pm \\
1.25\end{array}$ & $\begin{array}{c}6.63 \\
\pm \\
0.98\end{array}$ & $\begin{array}{c}5.64 \pm \\
0.91\end{array}$ & 0.173 & 0.088 & $\begin{array}{c}< \\
0.001\end{array}$ & 0.848 & 0.327 & $<0.001$ \\
\hline $\begin{array}{l}\text { Segmental } \\
\text { Height }\end{array}$ & $\begin{array}{r}31.32 \\
\pm 3.66\end{array}$ & $\begin{array}{c}33.23 \\
\pm \\
3.44\end{array}$ & $\begin{array}{c}32.66 \\
\pm 3.41\end{array}$ & $\begin{array}{c}31.57 \\
\pm 4.11\end{array}$ & $\begin{array}{c}33.50 \\
\pm \\
3.69\end{array}$ & $\begin{array}{c}32.14 \\
\pm 3.46\end{array}$ & 0.947 & 0.741 & $\begin{array}{c}< \\
0.001\end{array}$ & 0.002 & 0.490 & $\begin{array}{c}* 0.004 \\
\wedge<0.001\end{array}$ \\
\hline $\begin{array}{l}\text { Segmental } \\
\text { Cobb Angle }\end{array}$ & $\begin{array}{l}-1.19 \\
\pm 5.83\end{array}$ & $\begin{array}{c}1.89 \\
\pm \\
3.82\end{array}$ & $\begin{array}{c}0.46 \pm \\
4.19\end{array}$ & $\begin{array}{c}2.30 \pm \\
6.66\end{array}$ & $\begin{array}{c}2.53 \\
\pm \\
4.52\end{array}$ & $\begin{array}{c}1.20 \pm \\
3.94\end{array}$ & 0.034 & 0.477 & $\begin{array}{c}* * \\
<0.001 \\
\wedge 0.852\end{array}$ & 0.954 & 0.361 & 0.004 \\
\hline $\begin{array}{l}\text { Cervical } \\
\text { Cobb Angle }\end{array}$ & $\begin{array}{l}7.24 \pm \\
11.97\end{array}$ & $\begin{array}{c}11.75 \\
\pm \\
10.41\end{array}$ & $\begin{array}{c}11.37 \\
\pm 9.80\end{array}$ & $\begin{array}{c}10.96 \\
\pm 9.80\end{array}$ & $\begin{array}{c}10.46 \\
\pm \\
7.80\end{array}$ & $\begin{array}{c}11.02 \\
\pm 8.03\end{array}$ & 0.014 & 0.532 & $\begin{array}{c}* * \\
<0.001 \\
\wedge 0.759\end{array}$ & 0.519 & 0.623 & 0.999 \\
\hline
\end{tabular}




\begin{tabular}{|c|c|c|c|c|c|c|c|c|c|c|c|c|}
\hline Caudal level & & & & & & & \multicolumn{3}{|c|}{ Pre-op versus first post-op } & \multicolumn{3}{|c|}{$\begin{array}{c}\text { First post-op versus final post- } \\
\text { op }\end{array}$} \\
\hline Radiological & \multicolumn{3}{|c|}{ Triad $(n=53)$} & \multicolumn{3}{|c|}{ Peek $(n=35)$} & Interaction & Group & Time & Interaction & Group & Time \\
\hline & Preop & $\begin{array}{l}1^{\text {st }} \\
\text { post- } \\
\text { op }\end{array}$ & $\begin{array}{c}\text { Final } \\
\text { postop }\end{array}$ & Preop & $\begin{array}{c}1^{\text {st }} \\
\text { post- } \\
\text { op }\end{array}$ & $\begin{array}{c}\text { Final } \\
\text { postop }\end{array}$ & p-value & $\begin{array}{c}\mathrm{p}- \\
\text { value }\end{array}$ & $\begin{array}{c}\text { p- } \\
\text { value }\end{array}$ & p-value & $\begin{array}{c}\mathrm{p}- \\
\text { value }\end{array}$ & $\begin{array}{c}\mathrm{p}- \\
\text { value }\end{array}$ \\
\hline $\begin{array}{l}\text { Mean Disc } \\
\text { Height }\end{array}$ & $\begin{array}{c}3.58 \pm \\
1.09\end{array}$ & $\begin{array}{c}6.51 \pm \\
1.09\end{array}$ & $\begin{array}{c}5.40 \pm \\
0.92\end{array}$ & $\begin{array}{c}3.76 \pm \\
1.74\end{array}$ & $\begin{array}{c}6.57 \pm \\
1.06\end{array}$ & $\begin{array}{c}5.72 \pm \\
1.11\end{array}$ & 0.680 & 0.581 & $\begin{array}{c}< \\
0.001\end{array}$ & 0.384 & 0.272 & $\begin{array}{c}< \\
0.001\end{array}$ \\
\hline $\begin{array}{l}\text { Segmental } \\
\text { height }\end{array}$ & $\begin{array}{r}32.27 \\
\pm 3.51\end{array}$ & $\begin{array}{r}33.94 \\
\pm 3.43\end{array}$ & $\begin{array}{r}33.05 \\
\pm 3.41\end{array}$ & $\begin{array}{r}31.10 \\
\pm 3.41\end{array}$ & $\begin{array}{r}33.14 \\
\pm 3.50\end{array}$ & $\begin{array}{c}31.65 \pm \\
2.94\end{array}$ & 0.340 & 0.292 & $\begin{array}{c}< \\
0.001\end{array}$ & 0.017 & 0.050 & $<0.001$ \\
\hline $\begin{array}{l}\text { Segmental } \\
\text { Cobb angle }\end{array}$ & $\begin{array}{c}3.41 \pm \\
4.77\end{array}$ & $\begin{array}{c}6.95 \pm \\
4.38\end{array}$ & $\begin{array}{c}4.00 \pm \\
4.92\end{array}$ & $\begin{array}{l}2.25 \pm \\
6.06\end{array}$ & $\begin{array}{c}6.04 \pm \\
4.74\end{array}$ & $\begin{array}{c}3.25 \pm \\
5.26\end{array}$ & 0.811 & 0.280 & $\begin{array}{c}< \\
0.001\end{array}$ & 0.895 & 0.376 & $\begin{array}{c}< \\
0.001\end{array}$ \\
\hline
\end{tabular}

Mean \pm SD. Two-way Repeated Measures ANOVA. Interaction and main effects of groups and time of measurement were assessed. Significance level was set at $\mathrm{p}<0.05$.

*Allograft

^PEEK

Preop, preoperative; post-op, postoperation,

Table 4. Fusion and subsidence rate between the allograft and PEEK groups

\begin{tabular}{|c|c|c|c|}
\hline & $\begin{array}{c}\text { Allograft } \\
(\mathrm{n}=53)\end{array}$ & $\begin{array}{c}\text { Peek } \\
(\mathrm{n}=35)\end{array}$ & $\mathrm{p}$-value \\
\hline Cephalad level & & & \\
\hline Fusion & $51(98.1)$ & $35(100)$ & 1.000 \\
\hline Subsidence & $4(7.7)$ & $8(22.9)$ & 0.057 \\
\hline Caudal level & & & \\
\hline Fusion & $49(94.2)$ & $35(100)$ & 0.270 \\
\hline Subsidence & $8(15.4)$ & $13(37.1)$ & 0.020 \\
\hline
\end{tabular}

\section{Figures}



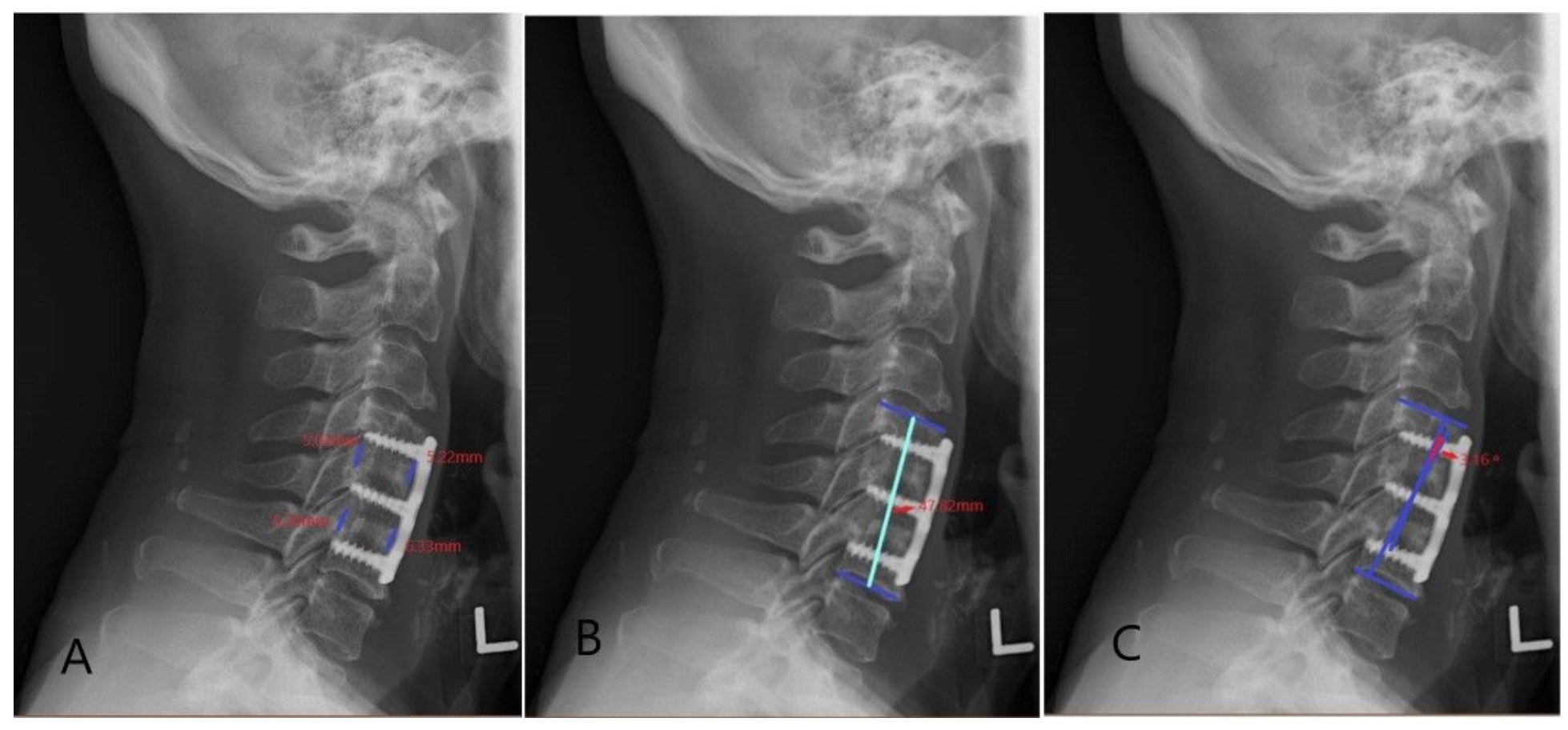

\section{Figure 1}

a) The measurement method for disc height: the mean value of the anterior and posterior disc height at each level; b) the measurement method for segmental height: the distance between the middle margin of the upper end plate of the superior vertebral body and the lower end plate of the inferior vertebral body; $c$ ) the measurement method for segmental Cobb angle/lordosis: the angle formed by the upper endplate of the superior vertebrae body and the lower endplate of the inferior vertebrae body, in neutral position. 